\title{
HUBUNGAN MEAN ARTERIAL BLOOD PRESSURE DENGAN KELUARAN PASIEN STROKE TROMBOTIK YANG DINILAI DENGAN SKOR NIHSS
}

\author{
Masruroh Rahayu*, Alidha Nur Rakhmani**, Neila Raisa**, Kurnia Auliyana Ar Rahmah*
}

\begin{abstract}
Abstrak
Hipertensi merupakan salah satu faktor risiko stroke. Beberapa penelitian menyatakan peningkatan tekanan darah sistol dan diastol pada stroke iskemik menyebabkan keluaran yang buruk pada pasien stroke. Namun berdasarkan penelitian lain, peningkatan tekanan darah sistemik memiliki efek proteksi sehingga menurunkan tingkat keparahan stroke. Penelitian ini bertujuan untuk mengetahui hubungan mean arterial blood pressure (MABP) dengan keluaran pasien stroke trombotik yang diukur dengan skor Delta National Institutes of Health Stroke Scale (NIHSS). Penelitian ini menggunakan subjek pasien stroke yang dirawat di Stroke Unit RS. Dr. Saiful Anwar Malang selama periode April - Juni 2016 dengan jumlah sample 30 pasien. Kriteria inklusi usia pasien $>18$ tahun, onset stroke $<24$ jam, dan diagnosis stroke dengan CT scan kepala sebagai gold standard. NIHSS dan tekanan darah diukur 24 jam pertama sejak terdiagnosis stroke dan NIHSS kembali diukur pada hari 14. Delta NIHSS didapatkan dari NIHSS hari ke 14 dikurangi NIHSS masuk. Penelitian ini menggunakan desain peneltian cross sectional. Berdasarkan hasil analisis didapatkan korelasi yang signifikan antara MABP dengan Delta NIHSS $(p=0,025, r=-0,408)$ dengan arah korelasi negatif. Semakin tinggi nilai MABP maka akan semakin negatif delta NIHSS. Semakin negatif nilai Delta NIHSS menunjukkan semakin baik klinis dari pasien stroke.
\end{abstract}

Kata kunci: delta NIHSS, MABP, sistol, diastol, stroke.

\section{THE CORRELATION BETWEEN MEAN ARTERIAL BLOOD PRESSURE AND STROKE THROMBOTIC PATIENT OUTCOME SCORED BY NIHSS}

\begin{abstract}
Hipertension is one of the risk factor of stroke. Some research state that the elevation of sistol and diastol in ischemic stroke have bad prognosis in stroke patient. But based on another research, state that elevation in sistemic blood pressure have protection efect that low stroke severity. This study aimed was to know the correlation between mean arterial blood pressure (MABP) and stroke thrombotic patient outcome scored by Delta NIHSS (National Institutes of Health Stroke Scale). This research used stroke patient in Dr. Saiful Anwar Hospital stroke unit as subject from April to June 2016 with number of sample 30 patients. The inclusion criteria was age $>18$ years old, stroke onset $<24$ hour, and stroke diagnosed by head CT scan as gold standard. NIHSS and blood pressure measured in the first 24 hour after diagnosis of stroke and NIHSS measured again in the $14^{\text {th }}$ day. Delta NIHSS obtained from NIHSS in the $14^{\text {th }}$ day minus NIHSS admission. In this study used cross sectional design. Based on the analysis results obtained a significant correlation between MABP with Delta NIHSS $(p=0.025, r=-0.408)$ with negative correlation direction. Higher MABP associate with more negative Delta NIHSS score. The more negative delta NIHSS score show clinical improvement of stroke patient.
\end{abstract}

Keywords: delta NIHSS, diastol, MABP, sistol, stroke.

* Departemen Neurologi, Fakultas Kedokteran Universitas Brawijaya

** Jurusan Pendidikan Dokter, Fakultas Kedokteran, Universitas Brawijaya

E-mail: kurniaaar@gmail.com 


\section{Pendahuluan}

Stroke adalah suatu gejala klinis yang berkembang cepat akibat gangguan fokal (atau global) dengan gejala-gejala yang berlangsung selama 24 jam atau lebih sehingga dapat menyebabkan kematian tanpa adanya penyebab selain vaskuler. ${ }^{1}$ Stroke diklasifikasikan menjadi dua jenis yaitu stroke akibat pendarahan dan iskemik. ${ }^{2}$ Stroke iskemik disebabkan karena penyumbatan yang dapat terjadi pada pembuluh darah arteri pada otak. Secara epidemiologi, stroke iskemik merupakan kasus stroke tersering sekitar $87 \%$ dari keseluruhan tipe stroke.1,3 Stroke iskemik terbagi menjadi dua yaitu stroke embolik dan stroke trombotik. Stroke trombotik terjadi akibat bekuan darah atau plak aterosklerosis yang menyumbat pembuluh darah di otak..$^{1,3}$

Hipertensi merupakan salah satu faktor risiko yang signifikan penyebab kejadian stroke, baik berdasarkan tekanan darah sistolik maupun diastolik. ${ }^{4}$ Hipertensi didefinisikan sebagai tekanan darah sistolik lebih dari atau sama dengan $140 \mathrm{mmHg}$ atau tekanan darah diastol lebih dari atau sama dengan $90 \mathrm{mmHg}$ pada usia 20 tahun, dan 160/95 mmHg pada usia 50 tahun ke atas. ${ }^{5}$ Tekanan darah tinggi (BP 140/90 $\mathrm{mm} / \mathrm{Hg}$, definisi oleh WHO) terjadi pada stroke akut hingga $75 \%$ kasus. $^{6}$ Data dari International Stroke Trial (IST) menunjukkan bahwa risiko kematian pada saat awal serangan stroke dan sesudahnya berhubungan dengan peningkatan tekanan darah sistolik (SBP) pada 17.398 pasien stroke. $^{7}$

MABP (mean arterial blood pressure) digunakan sebagai standar parameter peningkatan perfusi serebri (cerebral perfusion). MABP memiliki kolerasi dengan perfusi serebri dikarenakan autoregulasi vaskular oleh otak dan tekanan perfusi. MABP memiliki nilai akurasi diagnostik lebih baik daripada PP pada stroke iskemik. ${ }^{8}$ Pada acute neurologic event terjadi peningkatan tekanan darah sebagai reflex dari MABP untuk mempertahankan aliran darah otak terhadap neuron. ${ }^{9}$

Status neurologis penderita stroke dapat diukur dengan National Institutes of Health Stroke Scale (NIHSS). Pemeriksaan meliputi aspek neurologis, yaitu motorik, sensorik, kesadaran, dan fungsi luhur. Pemeriksaan ini memprediksi keluaran pasien baik untuk jangka panjang dan jangka pendek pasien stroke. ${ }^{2}$

Berdasarkan uraian di atas, peningkatan tekanan darah sistolik pada pasien stroke akut menunjukkan keluaran yang buruk. ${ }^{7}$ Peningkatan tekanan darah diastol berhubungan dengan risiko terjadinya stroke berulang. ${ }^{10,11}$ Namun pada penelitian lain kenaikan tekanan darah (sistolik $\geq 140$ $\mathrm{mmHg}$ dan/atau diastolik $\geq 90 \mathrm{mmHg}$ ) pada fase akut stroke iskemik menurunkan tingkat keparahan stroke.12 Oleh karena peningkatan tekanan darah sistol maupun diastol masih kontroversial terhadap prognosis stroke, maka dibutuhkan penelitian yang melibatkan tekanan darah sistol dan diastol, yaitu MABP yang dihubungkan dengan Skor NIHSS untuk mengetahui keluaran pasien stroke thrombotik.

\section{Bahan dan Metode}

Desain peneltian yang digunakan adalah studi cross sectional, yang bertujuan untuk mengetahui hubungan MABP dengan keluaran pasien stroke trombotik yang diukur menggunakan skor National Institute of Stroke Scale (NIHSS). Pada penelitian ini tidak terdapat kelompok kontrol. Sampel yang digunakan adalah pasien stroke yang dirawat di Unit Stroke RS. Dr. Saiful Anwar Malang. Pengambilan sampel ini menggunakan teknik konsekutif sampling dan didapatkan 30 sampel yang memenuhi kriteria inklusi yaitu: usia pasien $>18$ tahun, 
onset stroke $<24$ jam, dan diagnosis stroke dengan CT scan kepala sebagai gold sebagai berikut: penderita dengan riwayat stroke sebelumnya, penderita dengan riwayat keganasan, penderita dengan riwayat trauma, dan penderita dengan riwayat penyakit infeksi.

Sampel diambil dari rekam medik pasien stroke yang merupakan bagian dari penelitian yang berjudul "Uji Akurasi Kombinasi Kadar Glial Fibrillary Acidic Protein (GFAP) dan S100B Serum dengan Skor Siriraj sebagai Pembeda Tipe Stroke Akut". Pengambilan data untuk rekam medik dilaksanakan selama bulan April - Juni 2016 di RS. Dr. Saiful Anwar Malang.

Variabel bebas dalam penelitian ini adalah nilai MABP pasien stroke trombotik. Variabel tergantung pada penelitian ini adalah skor Delta NIHSS pasien. Hasil pengukuran tekanan darah pasien stroke trombotik dan hasil penilaian defisit neurologis menggunakan NIHSS dianalisis secara statistik melalui uji korelasi Pearson.

\section{Hasil}

Jumlah pasien stroke pada Unit Stroke RS. Dr. Saiful Anwar Malang pada April hingga Juni 2016 yang memenuhi kriteria inklusi adalah sebanyak 30 orang dengan frekuensi terbanyak subjek penelitian menurut jenis kelamin adalah laki-laki sebanyak 16 orang $(53,3 \%)$ (Tabel 1). Sementara itu, distribusi nilai MABP pasien stroke trombotik terbanyak pada kategori MABP di atas $\geq 132,34 \mathrm{mmHg}$ (Tabel 2). Tingkat keparahan stroke diklasifikasikan berdasarkan skor NIHSS, dan hingga saat ini klasifikasi ini masih digunakan untuk menggolongkan berbagai kategori NIHSS. ${ }^{12}$ Delta NIHSS merupakan data yang didapat dari hasil pengurangan NIHSS pulang (hari ke-14) dengan NIHSS Masuk (hari ke-0). Peningkatan atau penurunan skor NIHSS sebesar 4 atau lebih merupakan petanda standard. Kriteria eksklusi

klinis yang penting. ${ }^{13}$ "major clinical improvement" merupakan penurunan skor stroke sebesar 4 atau lebih. "major clinical detoriation" merupakan kematian atau kenaikan skor stroke sebesar 4 atau lebih. Pada penelitian ini didapatkan distibusi nilai NIHSS Masuk dan NIHSS Pulang pasien stroke trombotik terbanyak adalah pada kategori ringan-sedang. Sementara, distribusi nilai delta NIHSS pasien stroke terbanyak adalah pada kategori "major clinical improvement" (Tabel 3).

\begin{tabular}{ccc}
\hline Karakteristik & Frekuensi & Persentase (\%) \\
\hline $\begin{array}{c}\text { Jenis kelamin } \\
\text { Laki-laki }\end{array}$ & 16 & 53,33 \\
Wanita & 14 & 46,67 \\
Usia (tahun) & & \\
$\leq 44$ & 1 & 3,33 \\
$45-54$ & 5 & 16,67 \\
$55-64$ & 16 & 53,33 \\
$65-74$ & 5 & 16,67 \\
$75-84$ & 3 & 10 \\
$\geq 85$ & 0 & 0 \\
\hline Mean \pm SD & \multicolumn{2}{c}{$61,17 \pm 9,36$} \\
Minimum & \multicolumn{2}{c}{44} \\
Maksimum & \multicolumn{2}{c}{81}
\end{tabular}

Tabel 1. Karakteristik jenis kelamin dan usia pasien stroke

\begin{tabular}{|c|c|c|}
\hline $\begin{array}{l}\text { Nilai } \\
(\mathrm{mmHg})\end{array}$ & Frekuensi & Persentase (\%) \\
\hline$<93,33$ & 3 & 10 \\
\hline $93,33-99$ & 4 & 13,33 \\
\hline $99,01-105,67$ & 2 & 6,67 \\
\hline $105,68-119,00$ & 6 & 20 \\
\hline $119,01-132,33$ & 7 & 23,33 \\
\hline$\geq 132,34$ & 8 & 26,67 \\
\hline Mean \pm SD & & $118,23 \pm 19,83$ \\
\hline Minimum & & 83,33 \\
\hline Maximum & & 153,67 \\
\hline
\end{tabular}

Tabel 2. Data frekuensi nilai MABP 
Tabel 3. Data frekuensi nilai NIHSS

\begin{tabular}{|c|c|c|}
\hline NIHSS & Frekuensi & Persentase (\%) \\
\hline \multicolumn{3}{|l|}{ NIHSS Masuk } \\
\hline Ringan $(1-5)$ & 7 & 23,33 \\
\hline Ringan - Sedang $(6-14)$ & 15 & 50 \\
\hline Berat $(15-24)$ & 8 & 26,67 \\
\hline Sangat Berat $(\geq 25)$ & 0 & 0 \\
\hline Mean \pm SD & & $10,13 \pm 5,70$ \\
\hline Minimum & & 2 \\
\hline Maximum & & 22 \\
\hline \multicolumn{3}{|l|}{ NIHSS Pulang } \\
\hline Ringan $(1-5)$ & 11 & 36,67 \\
\hline Ringan-Sedang $(6-14)$ & 13 & 43,33 \\
\hline Berat $(15-24)$ & 2 & 6,67 \\
\hline Sangat Berat $(\geq 25)$ & 4 & 13,33 \\
\hline Mean \pm SD & & $9,53 \pm 7,88$ \\
\hline Minimum & & 0 \\
\hline Maximum & & 25 \\
\hline \multicolumn{3}{|l|}{ Delta NIHSS } \\
\hline Major Clinical Improvement $(\leq-4)$ & 9 & 30 \\
\hline Minor Clinical Improvement & 7 & 23,33 \\
\hline Major Clinical Detoriation ( $\geq 4$ ) & 3 & 10 \\
\hline Minor Clinical Detoriation & 6 & 20 \\
\hline No clinical Improvement (0) & 5 & 16,67 \\
\hline Mean \pm SD & & $-0,60 \pm 4,61$ \\
\hline Minimum & & -7 \\
\hline Maximum & & 10 \\
\hline
\end{tabular}

Tabel 4. Data frekuensi nilai sistol dan diatol

\begin{tabular}{lcl}
\hline Tekanan Darah & Frekuensi & Persentase (\%) \\
\hline Tekanan Darah Sistole $(\mathrm{mmHg})$ & & \\
$\quad<120$ & 0 & 0 \\
$120-139$ & 6 & 20 \\
$\quad 140-159$ & 2 & 6,67 \\
$\quad 2160$ & 22 & 73,33 \\
\hline Mean \pm SD & & $172,967 \mathrm{mmHg}$ \\
Minimum & & $120 \mathrm{mmHg}$ \\
Maximum & & $241 \mathrm{mmHg}$ \\
\hline Tekanan Darah Diastole $(\mathrm{mmHg})$ & 6 & 0 \\
$\quad<80$ & 5 & 20 \\
$\quad 80-89$ & 7 & 6,67 \\
$90-99$ & 12 & 73,33 \\
$\quad \geq 100$ & & $90,867 \mathrm{mmHg}$ \\
\hline Mean \pm SD & & $60 \mathrm{mmHg}$ \\
Minimum & & $120 \mathrm{mmHg}$ \\
Maximum & &
\end{tabular}


Berdasarkan Tabel 4 diketahui distribusi nilai tekanan darah sistol dan diastol pasien stroke trombotik terbanyak adalah pada kategori nilai tekanan darah $\geq 160 \mathrm{mmHg}$ dan $\geq 100 \mathrm{mmHg}$.

Penilaian korelasi antara nilai MABP dengan delta NIHSS dilakukan dengan uji korelasi Pearson. Hasil uji korelasi menunjukkan ada korelasi yang signifikan antara nilai MABP dengan variabel delta NIHSS $(p=0,025, p<0,05)$. Koefiesien korelasi Pearson $(r)=-0,408$ menunjukkan kedua variabel berkolerasi sedang dan arah hubungan negatif (-), sehingga disimpulkan nilai MABP berbanding terbalik dengan nilai delta NIHSS. Jika MABP naik maka delta NIHSS akan turun.

Penilaian korelasi antara nilai TDS dengan delta NIHSS dilakukan dengan uji korelasi Pearson. Hasil uji korelasi menunjukkan tidak ada korelasi yang signifikan antara nilai TDS dengan variabel delta NIHSS $(p=0,108 ; p<0,05)$. Penilaian korelasi antara nilai TDD dengan delta NIHSS dilakukan dengan uji korelasi Pearson. Hasil uji korelasi menunjukkan ada korelasi yang signifikan antara nilai TDD dengan variabel delta NIHSS $(p=0,018 ; p<$ $0,05)$. Penilaian korelasi antara nilai MABP dengan NIHSS Masuk dilakukan dengan uji korelasi Pearson. Hasil uji korelasi menunjukkan tidak ada korelasi yang signifikan antara nilai MABP dengan variabel NIHSS Masuk ( $p=0,374 ; p<0,05)$.

\section{Pembahasan}

\section{Karakteristik Responden}

Pada penelitan ini diketahui bahwa pasien laki-laki lebih banyak dari pada pasien wanita. Pada penelitian lain disebutkan bahwa prevalensi stroke pada usia 60-79 tahun adalah $6,2 \%$ untuk pria dan $6,9 \%$ untuk wanita, dengan risiko meningkat 2x lipat pada usia di atas 80 tahun, yaitu insiden $13,9 \%$ untuk pria dan $13,8 \%$ untuk wanita. ${ }^{14}$ Perbedaan ini dapat terjadi karena perbedaan ras, prevalensi faktor risiko penyakit, usia onset terjadinya stroke serta estimasi populasi yang berbeda antara Indonesia dengan Amerika Serikat. Selain itu, menurut Coulter (2015) laki-laki memiliki faktor risiko terkena stroke lebih besar daripada wanita. ${ }^{15}$ Namun wanita seiring dengan bertambahnya usia lebih mudah terkena stroke daripada pria.

Pada penelitian ini subjek penelitian adalah pasien stroke trombotik. Dari hasil penelitian didapatkan usia terbanyak pasien stroke pada kisaran usia 55-64 tahun dan usia rata-rata pasien adalah 61 tahun. Insiden stroke meningkat secara tajam seiring dengan peningkatan usia dan risiko stroke menjadi $2 x$ lipat semenjak usia 55 tahun. ${ }^{16}$ Pada usia 35-44 tahun, insiden stroke 30 hingga 120 per 100.000 jiwa setiap tahun. Sedangkan pada usia $65-74$, insiden stroke 670 hingga 970 per 100.000 jiwa setiap tahun. ${ }^{17}$ Hal ini menunjukkan stroke banyak terjadi pada usia di atas 60 tahun.

Distribusi Frekuensi MABP, NIHSS, TDS dan TDD

Pada penelitian ini distribusi frekuensi MABP pada pasien stroke didapatkan hasil terbanyak kategori MABP di atas $\geq 132,34$ $\mathrm{mmHg}$. Pada penelitian ini juga didapatkan hasil nilai rata rata MABP $118,23 \mathrm{mmHg}$, nilai minimum MABP $83,33 \mathrm{mmHg}$ dan nilai maksimum 153,67 mmHg. Pada penelitian yang dilakukan oleh Liqiang et al. (2008) di China menunjukkan hasil yang hampir serupa, frekuensi terbanyak kategori MABP pasien stroke adalah di atas $>127 \mathrm{mmHg}$ dengan nilai rata-rata MABP $118.41 \mathrm{mmHg}{ }^{7}$ 
Rodriguez (2001) menyatakan bahwa pada pasien stroke iskemik, target MABP adalah $120 \mathrm{mmHg}-140 \mathrm{mmHg} .{ }^{18}$ Chamorro et al. (1998) juga menyatakan bahwa turunnya nilai MABP sebanyak $>30 \%$ dari level basal menunjukkan penurunan tekanan darah yang signifikan. ${ }^{19}$ Penurunan MABP lebih dari $>15 \%$ menyebabkan penurunan aliran darah pada area iskemik penumbra .9

Pada penelitian ini distribusi frekuensi NIHSS Masuk pada pasien stroke didapatkan hasil terbanyak pada kategori ringan-sedang (skor 5-14). Nilai rata-rata NIHSS Pulang adalah 10 (kategori ringan sedang), nilai minimum 2, dan nilai maksimum 22. Berdasarkan penelitian yang dilakukan oleh Dowodu, dkk. (2008) pasien dengan NIHSS kategori ringan-sedang memiliki tingkat mortalitas $24,9 \%, 13,3 \%$ mengalami disabilitas berat, $36,6 \%$ mengalami disabilitas sedang, dan $50 \%$ sembuh total. ${ }^{20}$ Pada penelitian ini distribusi frekuensi delta NIHSS pada pasien stroke didapatkan hasil terbanyak pada kategori "Major Clinical Improvement". Nilai rata rata delta NIHSS adalah -0.6 , nilai minimum -7 dan nilai maksimum 10. Berdasarkan penelitian yang dilakukan oleh Young dae, et al. (2014), delta NIHSS menjadi prediktor yang signifikan untuk melihat mortalitas jangka panjang. ${ }^{21}$

Pada penelitian ini, distribusi frekuensi TDS dan TDD pada pasien stroke didapatkan hasil terbanyak pada kategori $\geq 160 \mathrm{mmHg}$ dan $\geq 100 \mathrm{mmHg}$. Nilai rata-rata TDS adalah $173 \mathrm{mmHg}$, maksimum TDS adalah $241 \mathrm{mmHg}$, dan minimum TDS adalah $120 \mathrm{mmHg}$. Sementara nilai rata-rata TDD adalah $90 \mathrm{mmHg}$, maksimum TDD adalah $120 \mathrm{mmHg}$, dan minimum TDD adalah $60 \mathrm{mmHg}$. Peningkatan tekanan darah biasanya terjadi pada saat awal stroke, namun menurun dengan spontan dalam jangka waktu 24 - 48 jam.6,13,22 Menurut Yatsu et al. (1985), peningkatan tekanan darah pasca stroke diperlukan untuk menyuplai aliran darah otak pada area iskemik. ${ }^{23}$ Berdasarkan uraian di atas dapat disimpulkan bahwa peningkatan tekanan darah sistol dan diastol terjadi pada stroke iskemik akut.

\section{Korelasi Nilai MABP dengan Delta NIHSS}

Hasil penelitian menunjukkan adanya korelasi signifikan antara MABP dengan delta NIHSS dengan arah hubungan yang negatif. Hal ini berarti semakin tinggi nilai MABP maka akan semakin negatif delta NIHSS yang menunjukkan "clinical improvement" dari pasien stroke. Sejalan dengan pernyataan Brott et al. (1992) bahwa penurunan skor NIHSS pulang pada pasien stroke sebesar 4 atau lebih merupakan "major clinical improvement", sedangkan peningkatan skor NIHSS pulang pada pasien stroke sebesar 4 atau lebih merupakan "major clinical detoriation". ${ }^{24}$

Berdasarkan uraian di atas maka nilai MABP pada pasien stroke perlu dipertahankan dalam kondisi optimum dan tidak boleh rendah karena berkaitan dengan keluaran pasien stroke trombotik. Qureshi et al. (2008) juga mengungkapkan bahwa pada pasien stroke iskemik nilai MABP harus ditingkatkan, karena nilai MABP normal $>60$ $\mathrm{mmHg}$ tidak cukup untuk mempertahankan aliran darah otak pada jaringan kapiler. Namun peningkatan MABP yang berlebihan perlu diwaspadai karena terdapat kurva hubungan $U$ antara MABP dengan tingkat morbiditas dan mortalitas pasien. ${ }^{2}$ Kurva $U$ merupakan gambaran statistik dari tingkat keluaran pasien yang buruk yang dihubungkan dengan nilai MABP yang terlalu rendah maupun terlalu tinggi. 


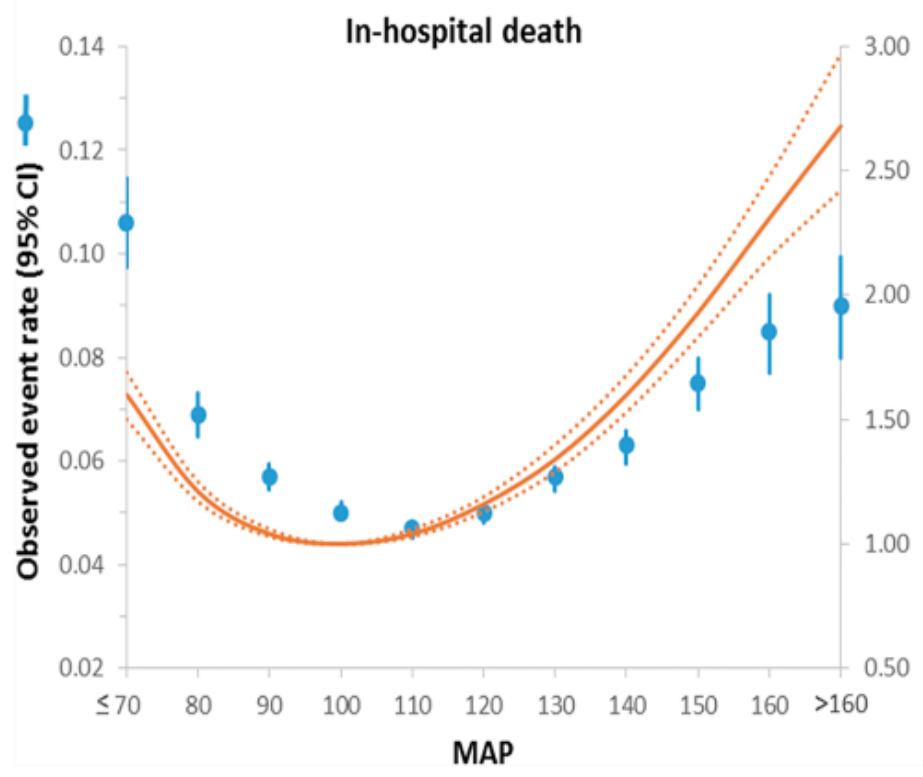

Gambar 1. Kurva U MABP

Mekanisme peningkatan MABP pada stroke iskemik dapat dijelaskan sebagai berikut, yaitu tekanan darah sistemik meningkat sebagai akibat dari respons alamiah mempertahankan perfusi dan sirkulasi kolateral untuk mensuplai aliran darah penumbra sehingga mencegah kerusakan iskemik lebih lanjut. ${ }^{12}$ Pada penelitian Astrup et al. (1977) menunjukkan bahwa iskemia akan bertambah parah jika tekanan darah iskemik diturunkan sebab sirkulasi kolateral tidak mampu menyuplai area penumbra. ${ }^{26}$

Pada stroke iskemik terjadi injuri pada otak sehingga mekanisme autoregulasi otak terganggu. Autoregulasi otak yang terganggu menyebabkan tekanan perfusi serebri juga terganggu. Padahal, tekanan perfusi serebri berperan penting untuk mengatur gradien aliran darah dari kapiler ke jaringan otak. Oleh karena itu, tubuh melakukan adaptasi untuk mempertahankan tekanan perfusi dengan menaikkan MABP agar tekanan intrakranial dapat diturunkan. Sehingga pengaturan aliran darah otak bergantung pada MABP. ${ }^{13}$ Peningkatan MABP terjadi akibat vasokontriksi yang menyebabkan peningkatkan tekanan darah.
Jika terjadi penurunan tekanan darah pada stroke iskemik maka akan menyebabkan vasodilatasi pembuluh darah otak. Vasodilatasi menyebabkan peningkatan volume darah otak. Peningkatan volume darah otak menyebabkan peningkatan tekanan intrakranial.23 Peningkatan intrakranial menyebabkan turunnya tekanan perfusi serebri sehingga terjadilah iskemia otak sekunder. Maka, untuk menghindari kerusakan otak sekunder setelah stroke, penurunan tekanan perfusi serebri harus dicegah.

Namun yang perlu diwaspadai adalah seiring dengan meningkatnya tekanan darah akibat vasokontriksi arteriol yang progresif sehingga melebihi batas atas toleransi autoregulasi otak. Hal ini dapat menyebabkan vasodilatasi secara tiba-tiba sehingga peningkatan berlebih aliran darah otak, disfungsi sawar darah otak, hingga terjadinya edema otak. ${ }^{24}$ Disfungsi sawar darah meningkatkan permeabilitas vaskular dan menyebabkan edema. Edema menghambat perfusi pada jaringan yang iskemik. ${ }^{25}$ Selain itu, perlu diwaspadai pula adanya "reperfusion injury" yang merupakan 
efek paradoksi dari pengembalian perfusi pada organ yang mengalami penurunan aliran darah. Walaupun mampu menyediakan suplai oksigen, namun hal ini memicu timbulnya respons imun innate, adaptif, sistem komplemen, platelet dan faktor koagulasi. Sehingga terjadilah kematian sel melalui berbagi mekanisme, yaitu nekrosis dengan ciri khas pembengkakan sel dan apoptosis yang melibatkan "signaling cell" yang rumit untuk kematian sel. ${ }^{26}$ Reperfusion injury juga diperparah oleh adanya radikal reactive oxide spesices yang ada pada otak dan jaringan lain. ${ }^{16,27}$ Kerusakan parenkim otak pada kondisi iskemia kemudian diikuti dengan "reperfusion injury" menyebabkan serangkaian tahap yang kompleks. Reperfusion injury dimulai dari interupsi aliran darah pada jaringan yang terkena, kemudian terjadi penurunan sumber energi sel dan glikolisis anaerob pada level substrat, lalu terjadilah asisodis laktat dan kegagalan pompa ion natrium-kalium, dikeluarkannya senyawa glutamat dan terjadilah edema sitotoksik, kemudian terbentuklah radikal bebas yang kemudian mengaktifkan respons imun innate dan adaptif. .7728 Reactive oxygen species juga memiliki efek terhadap unit neurovaskuler dan perubahan sel endotel sawar darah otak. ROS juga mempengaruhi fungsi astrosit yaitu dengan menghambat kemampuan repair astrosit dan 'detachment' sel dari membran basalis yang secara bersamaan merusak sawar darah otak. ${ }^{20}$ "Reperfusion injury" juga menyebabkan disfungsi dari mekanisme autoregulasi otak dan hilangnya kontrol terhadap aliran darah otak sehingga memperparah kerusakan.29,30

Berdasarkan uraian di atas, dapat disimpulkan bahwa peningkatan MABP diperlukan untuk mempertahankan tekanan perfusi serebri. Namun, peningkatan MABP yang melebih batas atas toleransi autoregulasi otak dapat menyebabkan edema, disfungsi sawar darah dan reperfusion injury.

Korelasi Nilai TDS dan TDD dengan Delta NIHSS

Penelitian ini bertujuan membuktikan kolerasi TDS dan TDD dengan keluaran pasien stroke trombotik yang diukur dengan Delta NIHSS. Hasil penelitian didapatkan korelasi yang tidak signifikan antara TDS dengan delta NIHSS dengan arah hubungan yang negatif. Sedangkan, pada penelitian ini didapatkan korelasi yang signifikan antara TDD dengan delta NIHSS dengan arah hubungan yang negatif. Jadi, dapat dinyatakan semakin tinggi nilai TDD maka semakin rendah nilai delta NIHSS. TDD yang rendah menyebabkan insufisiensi gradien tekanan darah diastol sehingga perfusi organ vital berkurang. Maka dari itu, seiring dengan meningkatnya usia, TDD semakin rendah dan TDS semakin tinggi akibat adanya kakuan pembuluh darah arteri. ${ }^{31}$ Namun, perlu diwaspadai pula, karena menurut penelitian Castillo et al. (2004), terdapat hubungan kurva $U$ pada TDS dan TDD. Kurva $U$ menggambarkan statistik dari nilai TDS dan TDD yang terlalu rendah atau terlalu tinggi memiliki hubungan dengan keluaran pasien stroke yang buruk. ${ }^{31}$ 

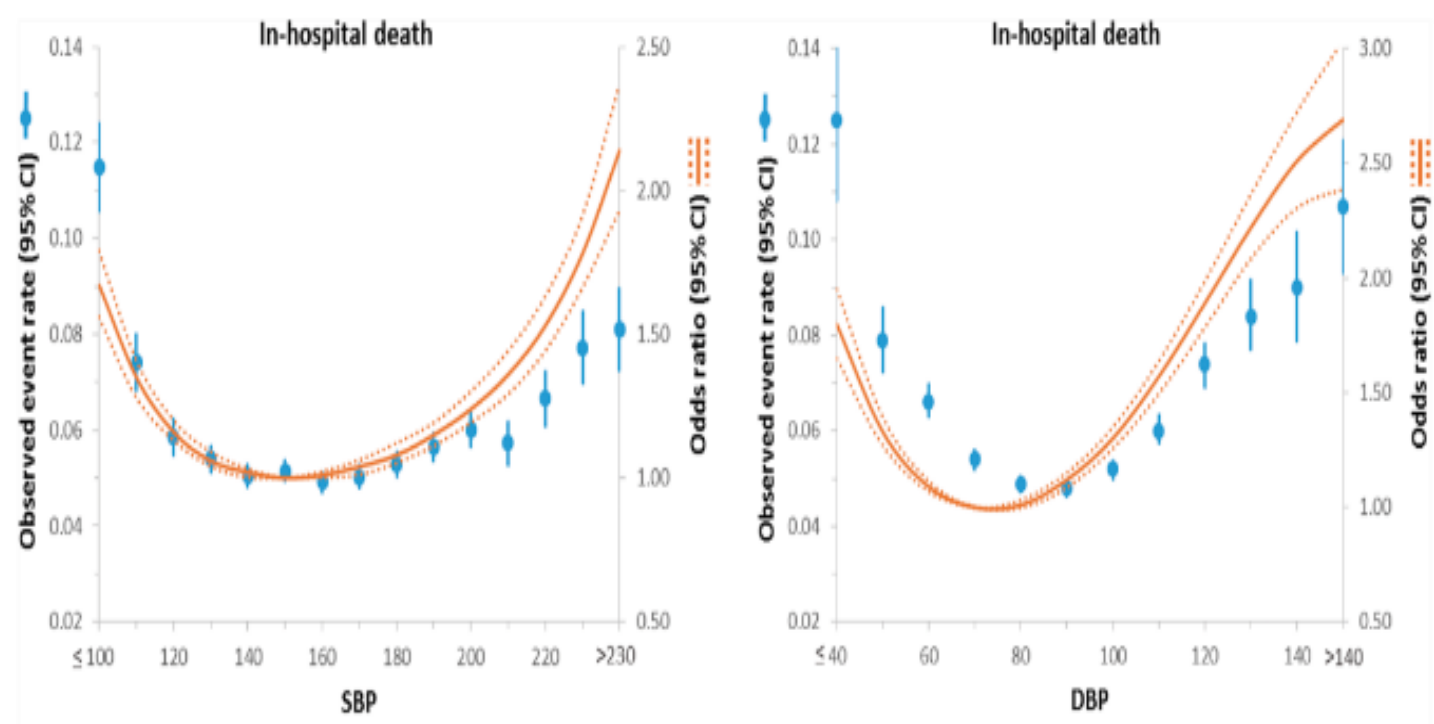

Gambar 2. Kurva U TDS dan TDD (Bangalore, 2017)

Korelasi MABP dengan NIHSS Masuk

Hasil penelitian menunjukkan ada korelasi yang tidak siginifikan antara MABP dengan NIHSS masuk. Pada penelitian yang dilakukan oleh Rianawati, dkk. (2014) juga menunjukkan bahwa tidak ada korelasi yang signifikan antara MABP dengan NIHSS Masuk. ${ }^{32}$

\section{Keterbatasan Penelitian}

Pada penelitian ini tidak disertai pengukuran BMI (Body Mass Indeks) dan Lingkar Perut pasien. Pada penelitian ini juga tidak melakukan "follow up" pengukuran tekanan darah saat pasien dipulangkan untuk mengetahui prognosis dari pasien. Selain itu, pada penelitian juga tidak menilai korelasi antara penggunaan obat antihipertensi dengan keluaran pasien.

\section{Kesimpulan}

Dari hasil penelitian dapat ditarik kesimpulan bahwa ada korelasi yang signifikan antara MABP dengan delta NIHSS. Serta pada penelitian ini dapat ditarik kesimpulan bahwa tidak ada korelasi yang signifikan antara TDS dengan delta NIHSS, ada korelasi yang signifikan antara TDD dengan delta NIHSS, dan tidak ada korelasi yang signifikan antara MABP dengan NIHSS masuk.

\section{Saran}

Berdasarkan hasil kesimpulan penelitian di atas, maka beberapa saran yang dapat disampaikan antara lain yaitu :

1. Perlu dilakukan penelitian lanjutan tentang hubungan penggunaan obat antihipertensi dengan Delta NIHSS.

2. Perlu dilakukan penelitian lanjutan untuk mencari cut off range MABP pada pasien stroke trombotik.

3. Perlu dilakukan penelitian lanjutan terhadap MABP pada masa perawatan pasien stroke trombotik dengan keluaran pasien.

\section{Daftar Pustaka}

1. Adams HP, Adam RJ, Brott T, del Zoppo GJ, Furlan A, Goldstein LB, Grubb RL, Higashida R, Kidwell C, Kwiatkowski TG, Marler JR, Hademenos GJ. Guidelines for Early Management of Patients with 
Ischemic Stroke. Stroke. 2007; 34:10561077.

2. National Institute of Health, National Institute of Neurological Disorders and Stroke. Stroke Scale. (Online). http://www.ninds.nih.gov/doctors/NIH_Str oke_Scale.pdf.

3. Adams HP, Bendixen BH, Kappelle LJ, Biller J, Love BB, Gordon DL, Marsh EE. Classification of Subtype of Acute Ischemic Stroke. Definitions for Use in A Multicenter Clinical Trial. TOAST. Trial of Org 10172 in Acute Stroke Treatment. Stroke. 1993; 24(1):35-41.

4. Bustan MN.. Epidemiologi Penyakit Tidak Menular. Cetakan ke- 2. Jakarta: Rineka Cipta. 2007.

5. Smeltzer dan Bare. Buku Ajar Keperawatan Medikal Bedah. Yasmin Asih (Penerjemah) . Jakarta: Buku Kedokteran EGC. 2002.

6. Britton M, Carlsson A, de Faire U. Blood Pressure Course in Patients with Acute Stroke and Matched Controls. Stroke. 1986; 17:861-864.

7. Leonardi-Bee J, Bath PM, Phillips SJ, Sandercock PA, Blood Pressure and Clinical Outcome in International Stroke Trial. PUB MED. 2002; 33(5):1315-20.

8. Zheng L, Sun Z, Li J, Zhang R, Zhang $X$, Liu S, Li J, Xu C, Hu D, Sun Y. Pulse Pressure and Mean Arterial Pressure in Relation to Ischemic Stroke Among Patients with Uncontrolled Hypertension in Rural Areas of China. AHA JOURNAL. 2008; 39:1932-1937.

9. Melanson P. Optimal Management of Blood Pressure in Acute Stroke. McGill Critical Care Medicine. 1999; 1:1-2.

10. Willmot M, Leonardi-Bee J, Bath PM. High Blood Pressure in Acute Stroke and Subsequent Outcome: A Systematic Review. Hypertension 2004; 43:18-24.

11. Willmot M, Leonardi-Bee J, Bath P.M. High Blood Pressure in Acute Stroke and Subsequent Outcome: A Systematic Review. Hypertension. 2004; 43:18-24.

12. Kvistad CE, Logallo $\mathrm{N}$, Oygarden $\mathrm{H}$, Thomassen L, Waje-Andreassen $U$,
Naess H. Elevated Admission Blood Pressure and Stroke Severity in Acute Ischemic Stroke: the Bergen NORSTROKE Study. Cerebrovasc Dis. 2013; 36(5-6):351-4.

13. Brott T, HP Adams Jr, CP Olinger, JR Marler, WG Barsan, J Biller, J Spilker, R Holleran, R Eberle, V Hertzberg, M Rorick, CJ Moomaw, and M Walker. Measurements of Acute Cerebral Infarction: A Clinical Examination Scale. Stroke. 1989; 20:964-970.

14. Go AS, Mozaffarian D, Roger VL, et al. Heart Disease and Stroke Statistics-2013 Update: A Report from the American Heart Association. Circulation. 2013; 127(1):e6-e245.

15. Coulter S. More Strokes for Men; More Deadly for Women. Texas Heart Institute. 2015. (Online). http://www.texasheart.org/HIC/WomenHe art/director2015-06.cfm. Diakses pada 7 Desember 2017.

16. Chong JY, Sacco RL. Epidemiology of Stroke in Young Adults: Race/Ethnic Differences. J Thromb Thrombolysis. 2005; 20:77-83. doi: 10.1007/s11239005-3201-9.

17. Roger VL, Go AS, Lloyd-Jones DM, et al. Heart Disease and Stroke Statistics-2011 Update: a report from the American Heart Association. Circulation. 2011; 123(4):e129-e153.

18. Rodriguez $F$, Bonacasa $B$, Fenoy $F J$, Salom MG. Reactive Oxygen and Nitrogen Species in the Renal Ischemia/Reperfusion Injury. Curr Pharm Des. 2013; 19:2776-2794.

19. Chamorro A, N Villa, C Ascaso, E Elices, W Schonewilla, R Blanc. Blood Pressure and Functional Recovery in Acute Ischemic Stroke. Stroke. 1998; 29:18501853. doi: 10.1161/01.STR.29.9.1850.

20. Dawodu CO, Danesi MA. Relationship of National Institute of Health Stroke Scores [NIHSS] to 90 Days Mortality In Africa. Niger Postgrad Med J. 2008; 15(4):25963. 
21. Kim YD, Song D, Kim EH, Lee KJ, Lee $\mathrm{HS}$, Nam CM, Nam HS, and Heo JH. Long-Term Mortality According to the Characteristics of Early Neurological Deterioration in Ischemic Stroke Patients. Yonsei Med J. 2014; 1: 55(3): 669-675.

22. Potter JF, Robinson TG, Ford GA, Mistri $A$, James $M$, Chernova $J$, et al. Controlling Hypertension and Hypotension Immediately Post-Stroke (CHHIPS): a Randomised, PlaceboControlled, Double-Blind Pilot Trial. Lancet Neurol. 2009;8:48-56.

23. Yatsu FM, Zivin J. Hypertension in Acute Ischemic Strokes. Not To Treat. Arch Neurol. 1985; 42:999-1000.

24. Brott T, Adams HP Jr, Olinger CP, Marler JR, Barsan WG, Biller J, Spilker J, Holleran R, Eberle R, Hertzberg V. Measurements of Acute Cerebral Infarction: A Clinical Examination Scale. Stroke. 1989; 20(7):864-870.

25. Qureshi Al. Acute Hypertensive Response in Patients with Stroke: Pathophysiology and Management. Circulation. 2008; 118:176-187.

26. Astrup J, Symon L, Branston NM, Lassen NA. Cortical Evoked Potential and Extracellular $\mathrm{K}$ _and $\mathrm{H}_{-}$at Critical Levels of Brain Ischemia. Stroke. 1977; 8:51-57.

27. Rodriguez R. Hypertension \& Acute Neurologic Patients. 2001.

28. Dirnagl U, Ladecola C, Moskowitz MA. Pathobiology of Ischaemic Stroke: an
Integrated View. Trends Neurosci. 1999; 22:391-397.

29. Cipolla MJ, McCall AL, Lessov N, Porter JM. Reperfusion Decreases Myogenic Reactivity and Alters Middle Cerebral Artery Function After Focal Cerebral Ischemia In Rats. Stroke. 1997; 28:176180.

30. Nishigaya $K$, Yoshida $Y$, Sasuga $M$, Nukui $H$, Ooneda $G$. Effect of Recirculation on Exacerbation of Ischemic Vascular Lesions in Rat Brain. Stroke. 1991; 22:635-642.

31. Castillo J, Leira R, García MM, Serena J, Blanco M, Dávalos A. Blood Pressure Decrease During The Acute Phase of Ischemic Stroke is Associated with Brain Injury and Poor Stroke Outcome. Stroke 2004; 35: 520-526.

32. Rianawati SB, Aurora H, Nugrahanitya Y. Correlation betwen Blood Pressure at Admitted Emergency Room and Clinically Outcome in Acute Thrombotic Stroke Patients. Malang Neurology Jouranal. 2015;1(2):68-71. 